\title{
東洋大学の 4 箇所のキャンパスにおけるエネルギー消費量に関する調査研究 STUDY ON ENERGY CONSUMPTION AT FOUR CAMPUSES OF TOYO UNIVERSITY
}

\author{
永峯 章*, 高草木 明**, 成 實 悠 樹***, 吉 野大 輔**** \\ Akira NAGAMINE, Akira TAKAKUSAGI, Yuuki NARUMI \\ and Daisuke YOSHINO
}

\begin{abstract}
This study aims to provide basic data for energy management at university campus. Investigating building maintenance logs at each campus of Toyo University, effecting factors on energy consumption are examined with multiple regression analysis. It reveals that the explanatory variables are outer temperature, number of student, duration of school term days and total floor space. This analysis shows each impact of the explanatory factors on the energy consumption as the dependent variable. This paper also compares energy consumption at 4 campuses.
\end{abstract}

Keywords: University, Campus, Energy Management, Energy Consumption, Multiple Regression Analysis 大学，キャンパス，エネルギー管理，エネルギー消費量，重回帰分析

はじめに

建物運用における省エネルギー推進のためには、個々の建物での エネルギー消費量の実態を把握し評価することが極めて重要である。

多くの建物での光熱水の調査結果から、平均值としての原単位を 求める研究は長年にわたって数多くの有用なデー夕を提供してきた 1)。光熱水原単位を利用寸る業務の一つは、個々の建物におけるエ ネルギー管理である。しかし、月間あるいは年間のエネルギー消費 実績值を評価するための基準值としては原単位では不足である。

高草木 ${ }^{2)}$ は建物運営管理におけるエネルギー消費量の妥当性の評 価は、エネルギー消費実績に説明がつくかどうかであるとして、6 件のエネルギー源が電気だけの中小賃貸事務所建物の長期的な電気 消費量の記録に基づき、電気消費量の変動要因を挙げ、これらに対 応する説明変数を検討し、電気消費量を目的変数とする重回帰によ り、それぞれの変動要因の影響を分析した。これにより既存建物に おいて過去の実績から管理基準值（当該建物の諸事情、諸特性に対 して標準的な電気消費量）を求める方法を示し、この分析の過程に おいて、建物の使われ方により電気消費量が受ける影響の実態例を 提示した。

また、小松と高草木 ${ }^{3)}$ とは、地域熱供給を受けている延床面積 $25,462 \mathrm{~m}^{2}$ の中規模事務所建物における 14 年余の熱使用量の記録 により、重回帰分析によるエネルギー管理への基礎資料提供を目的 とした調查研究を行っている。

このような研究は、調查事例を増やすことが重要であり、また、 調查対象をエネルギー消費特性の異なる様々な用途の建物に拡大し てゆくことが課題である。
日本には全国に 773 の大学（平成 21 年度文部科学省）があり、 キャンパスは大方が大規模施設であるから省エネルギー努力が注が れることの効果は大きい。夏（8月、9月）と春（2月、3月）に 長期の休暇がある。また、キャンパス内での建物の増改築や学生数 の変動も多い。これらはエネルギー消費特性に特殊な影響を与えて いることは明らかである。大学キャンパスのエネルギー消費の実態 や特性を明らかにすることは意義が大きいと考えられる。

大学キャンパスはファシリティマネジメント（FM）の対象とし て関心が持たれ、関連する報告も増えている ${ }^{4)}$ 。その中でエネルギ 一消費についても触れられていることが多い。また、新規性の高い 設備システムを導入したキャンパスにおいて、実測データによりそ の効果を検証した事例の報告もある5）6)。これらの他、大学キャ ンパスのエネルギー消費量に関する調查の報告もいくつか見られる 7) 13)。しかし、大学キャンパスのエネルギー消費量に影響する要 因について分析した既往研究は見当たらない。著者らは、著者らが 所属する東洋大学の 4 箇所のキャンパスのエネルギー消費に関する 長期の記録を調查し、これに影響を与える要因を検討して重回帰分 析を行った。

本調查研究は、説明変数とした要因それぞれの、目的変数である エネルギー消費量への影響の大きさを明らかにし、またキャンパス 間でのエネルギー消費についての比較を加え、エネルギー管理への 基礎資料を提供することを目的とする。

\section{1. 調査主旨と調査概要}

建築設備の運転管理におけるエネルギー消費量の管理の重要性は

\footnotetext{
* 東洋大学理工学部建築学科 講師

*** 東洋大学理工学部建築学科 教授・博士 (工学)

*** 安藤建設株 (研究当時 東洋大学工学部建築学科)

**** 東洋大学環境デザイン尃攻 博士前期課程
}

Instructor, Department of Architecture, Faculty of Engineering, Toyo Univ. Prof., Department of Architecture, Faculty of Engineering, Toyo Univ., Dr. Eng. Ando Corporation

(Then: Student, Toyo Univ.)

Graduate Student, Toyo Univ. 
広く認識されるところであり、空調設備に対しては中原らによる BOFDDなどの管理手法が提案されている14) 15)。しかし、実際の保 全現場におけるその実態を見ると、運転シミュレーションとの対応 等によりエネルギー消費実態の精密な分析を行い、問題点を明確に 把握するといった高水準な管理の実現性は遠いことが感じられる。 保全現場に時間的・技術的余裕があったとしても、妥当なエネルギ 一消費量を正確に求めるための建物運用に関わる諸条件、諸事情を 正確に把握することは極めて難しいから、運転実績の高水準な評価 は容易でない。

現状では、エネルギー消費量の計量も一般に十分な計測器が備わ っていない。エネルギー使用量を詳細に把握するための系統別計測 器の設置の重要性は、かねてより多くの設備技術者が指摘するとこ ろであるが、詳細な計測結果が当該建物経営にどの程度の利をもた らすかを明確に示寸ことは難しく、その実現は稀である。多数の計 測器設置を前提とし、詳細な分析を行う管理方法の研究とは別に、 実情を前提条件とし、エネルギー管理の改善を目指寸努力も必要と 思われる。

エネルギー管理の基本はエネルギー使用量が妥当かどうかの診断 である。これを簡単に行う方法は管理基準值との対照である。保全 現場でエネルギー消費量の実績を評価する簡易な方法として、当該 施設の前年同月実績との比較と、他の多くの同種の建物の平均值 (原 単位）との比較が採用されていることが多い。しかし、エネルギー 使用量には様々な変動要因があり、これらの有効性は薄い。

エネルギー消費量の妥当性の診断とは、消費量実績について説明 がつくかどうかであると考えられる。本論文では、エネルギー消費 量実態データに基づき、電気、ガス、重油、灯油消費量の変動要因 を挙げ、これらに対応する説明変数を検討し、電気、ガス、重油、 灯油およびこれらを合計した 1 次エネルギー消費量を目的変数とし て重回帰により、それぞれの変動要因の影響の程度を分析するとと もに、過去の実績から簡易に管理基準值（当該施設の諸事情、諸特 性に対して標準的なエネルギー使用量) を求める方法を示している。 これは、「当該施設の前年同月実績との比較」の方法を発展させたも のである。一方、「原単位との比較」の手法の敷衍として第 3 節に延 床面積あたり原単位と学生数あたり原単位の比較を加えて、キャン パス間のエネルギー消費量比較の結果を示している。

調查対象の東洋大学は、白山、川越、朝霞、板倉の 4 箇所にキャ ンパスを持つ総合大学である。現在（2009 年）、9学部が置かれて いる。各キャンパスの概要を表 1 に示す。白山第 2 キャンパスは対 象外と寸る。各キャンパスの建物の空調方式を表 2 に示す。

以降、「白山キャンパス」は「白山」というように、「キャンパス」 を省いて設置されている地名のみで表記する。

各キャンパスの電力、ガス、重油、灯油の消費量の調查を行い、 得られたデータの期間を表 3 に示す。白山、川越、朝霞、板倉は電 カとガスとを使用している。ガスについては、白山は都市ガス、朝 霞は都市ガスと L P ガス併用、川越、板倉はＬＰガスである。油に ついては、川越は重油、朝霞は灯油である。

\section{2. エネルギー消費量の分析}

\section{1 分析の方針と説明変数}

エネルギー消費量は月間の消費量を対象とし、これを目的変数と
表 1 東洋大学各キャンパス概要

\begin{tabular}{|c|c|}
\hline \multirow{3}{*}{\begin{tabular}{|c|} 
白山第 1 キャンパス \\
文系学部
\end{tabular}} & 東京都文京区白山 \\
\hline & $\begin{array}{l}\text { 文学部／経済学部／経営学部／法学部／社会学部／ } \\
\text { イブニングコース (第 } 2 \text { 部) /大学院 }\end{array}$ \\
\hline & 1 号館 6 号館 \\
\hline \multirow{3}{*}{$\begin{array}{c}\text { 白山第 } 2 \text { キャンパス } \\
\text { (対象外) }\end{array}$} & 東京都文京区白山 \\
\hline & 専門職大学院（法科大学院）／大学院 \\
\hline & $\mathrm{A}$ 棟〜D棟 \\
\hline \multirow{3}{*}{$\begin{array}{l}\text { 川越キャンパス } \\
\text { 理系学部 }\end{array}$} & 埼玉県川越市鯨井 \\
\hline & 工学部 /大学院 \\
\hline & $\begin{array}{l}1 \text { 号館〜 } 6 \text { 号館, 図書館・メディアセンター, } \\
\text { 各種実験棟, 福利厚生棟, その他 } \\
\end{array}$ \\
\hline \multirow{3}{*}{$\begin{array}{c}\text { 朝霞キャンパス } \\
\text { 文系学部+理系学部 }\end{array}$} & 埼玉県朝霞市岡 \\
\hline & ライフデザイン学部／大学院 \\
\hline & $\begin{array}{l}\text { 講義棟, 情報実習棟, 研究管理棟, 大学院·研究棟, } \\
\text { 総合体育館, コミュニティセンター }\end{array}$ \\
\hline \multirow{3}{*}{$\begin{array}{l}\text { 板倉キャンパス } \\
\text { 文系学部十理系学部 }\end{array}$} & 群馬県邑楽郡板倉町 \\
\hline & 国際地域学部／生命科学部／大学院 \\
\hline & 1 号館 3 号館, 図書館, 食堂棟, 研究棟 \\
\hline
\end{tabular}

表 2 空調システム

\begin{tabular}{|c|l|}
\hline 白山 & $\begin{array}{l}\text { ガス焚二重効用吸収式冷温水発生機による中央方式, } \\
\text { ウォールスルーペリメータ空調, パッケージ空調 }\end{array}$ \\
\hline 川越 & 分散型パッケージ空調一部スチーム暖房 \\
\hline 朝霞 & $\begin{array}{l}\text { ガス焚二重効用吸収式冷温水発生機による中央方式, } \\
\text { 分散型パッケージ空調 }\end{array}$ \\
\hline 板倉 & $\begin{array}{l}\text { ガス焚二重効用吸収式冷温水発生機による中央方式, } \\
\text { 分散型パッケージ空調 }\end{array}$ \\
\hline
\end{tabular}

表 3 エネルギー消費量データの取得期間

\begin{tabular}{|c|c|c|}
\hline 白山 & $\begin{aligned} & \text { 電気 : } 1998 \text { 年 } 4 \text { 月〜2009年3月 } \\
& \text { ガス : } 2000 \text { 年 } 4 \text { 月〜2009年3月 } \\
& \text { ガスの2003年11月は異常值のため除外 }\end{aligned}$ & $\begin{array}{l}132 \text { ケ月 } \\
108 \text { ケ月 }\end{array}$ \\
\hline 川起 & 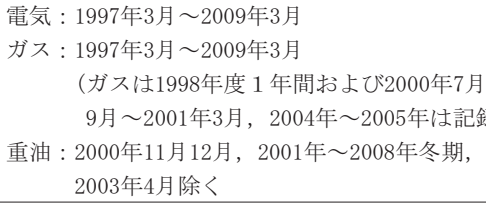 & $\begin{array}{l}145 \text { ケ月 } \\
101 \text { ケ月 } \\
\text { ，2000年 } \\
\text { 录欠落） } \\
\text { 49ケ月 }\end{array}$ \\
\hline 朝 & $\begin{aligned} \text { 電気 : } 2005 \text { 年 } 4 \text { 月〜 } 2009 \text { 年 } 3 \text { 月 } \\
\text { ガス : } 2005 \text { 年 } 4 \text { 月〜 } 2009 \text { 年 } 3 \text { 月 } \\
\text { 灯油 : } 2005 \text { 年 } 2008 \text { 年 } 1,2,4,7,8,11,12 \text { 月, } \\
\\
2005 \text { 年 } 1,2 \text { 月除く }\end{aligned}$ & $\begin{array}{l}48 \text { ケ月 } \\
48 \text { ケ月 }\end{array}$ \\
\hline 板倉 & $\begin{array}{l}\text { 電気：1997年3月～2009年2月 } \\
\text { ガス：1997年4月〜2008年12月 }\end{array}$ & $\begin{array}{l}144 \text { ヶ月 } \\
141 \text { ケ月 }\end{array}$ \\
\hline
\end{tabular}

したとき、説明変数として、キャンパス内建物延床面積、学生数、 開講日数、平均外気温度を考えることとする。原単位は通常、延床 面積あたりのエネルギー消費量であり、これを目的変数とすること も考えられるが、調查対象期間中、延床面積には少なからず変化が あるため延床面積を説明変数の一つとした。川越の場合、学生数と の相関性は低く独立変数たり得ることを確認した注 1 )。

空調設備の運用では、大規模事務所ビルなどと異なり、明確に冷 房と暖房とが切り替えられている。従って、分析は夏期 $(4$ 月 10 月）と冬期（11月～3月）とに分けて行うこととした。

各キャンパスの建物延床面積の月変動を図 1 に示寸。図 2 は学生 数の変動である注2)。これは年度毎に一定としている。これらは表 3 の電気消費量データの取得期間に対応した期間のデータのみ示し ている。図 3 は年間の各月開講日数である。キャンパスによって相 違がある。この図は川越キャンパスの場合である。開講日数は過去 のデータが無く、毎年ほとんど変化がないのでキャンパス毎に毎年 


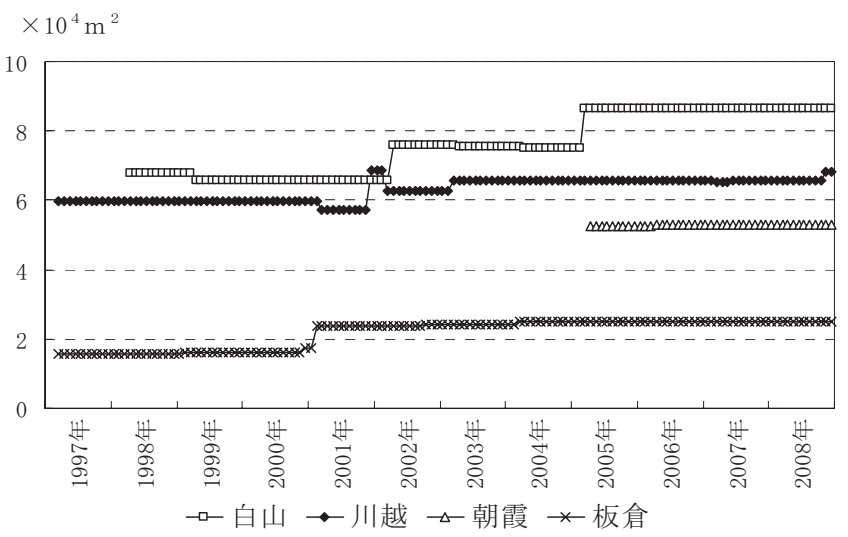

図 1 各キャンパスの建物延床面積の月変動

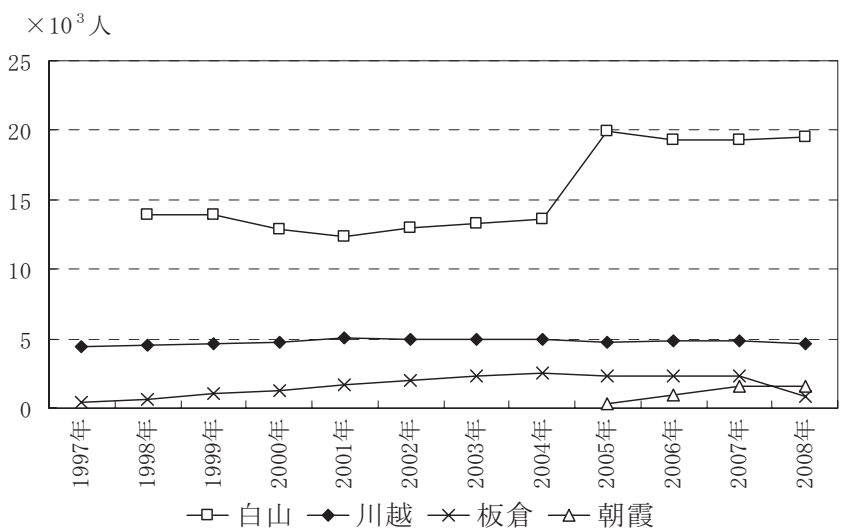

図 2 学生数の年度変動

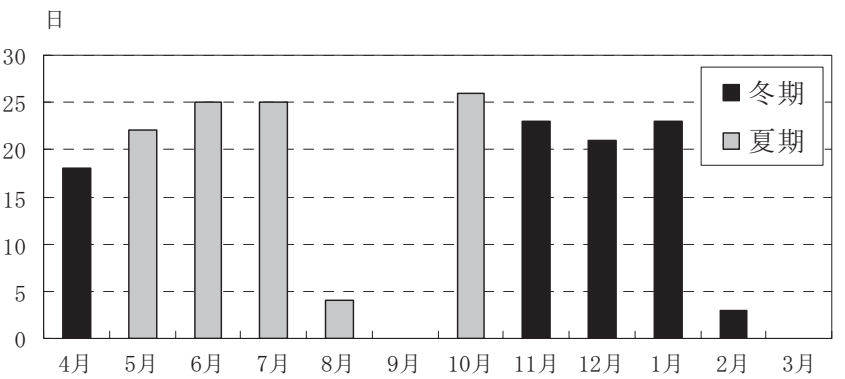

図 3 年間の各月開講日数 (川越 $)$

一定とした注2)。

平均外気温度は、東京 (白山)、さいたま市 (川越)、所沢 (朝霞)、 館林（板倉）の気象庁のデータである。

\section{2 エネルギー消費量}

各キャンパスの月間電気消費量の変動を図 4 に示す。また、図 5 には、月間ガス消費量の変動を示す。各キャンパスのガスの用途を 表 4 に示寸。

電気、ガス、重油、灯油を 1 次エネルギーに換算し合計した月間 1 次エネルギー消費量の変動を図 6 に示す。

1 次エネルギー換算には、

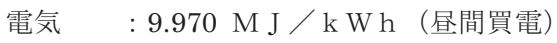

都市ガス : $45.00 \mathrm{M} \mathrm{J} / \mathrm{m}^{3}$ (都市ガス 13A)

L Pガス : $104.1 \mathrm{M} \mathrm{J} / \mathrm{m}^{3}$

重油 : $39.1 \mathrm{M} \mathrm{J} / \mathrm{m}^{3}$ $\times 10^{5} \mathrm{kWh} /$ 月

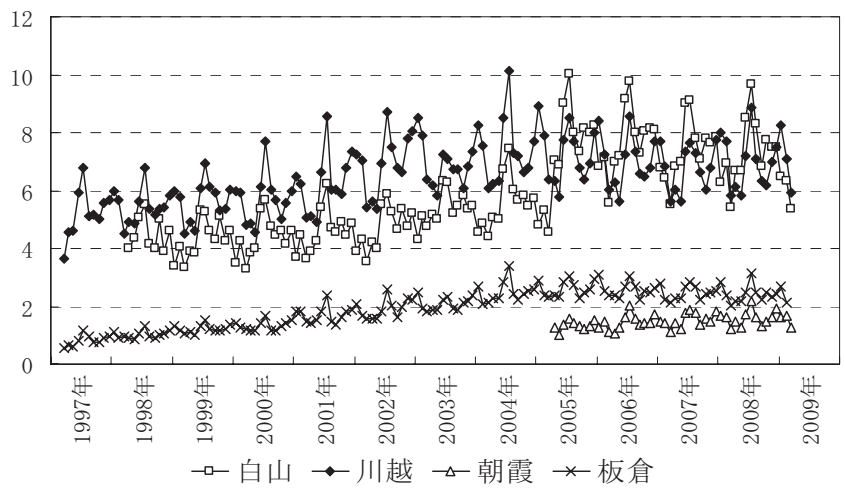

図4 各キャンパスの月間電気消費量の変動

$\times 10^{5} \mathrm{M} \mathrm{J} /$ 月

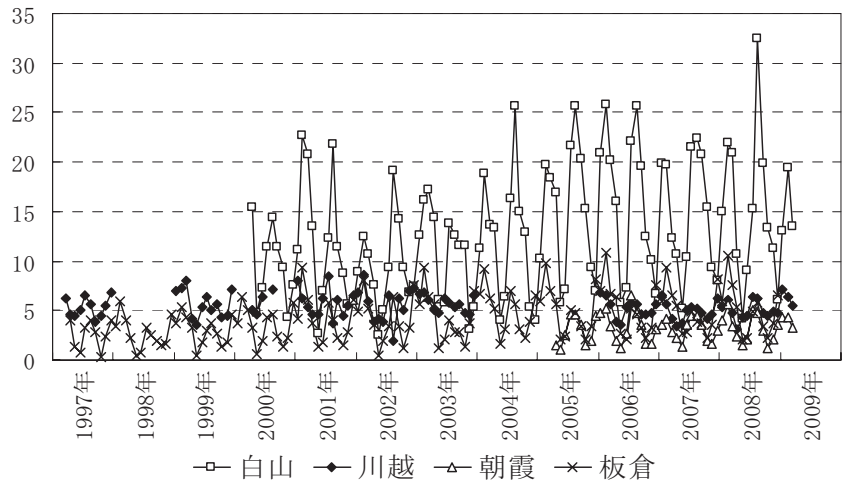

図 5 各キャンパスの月間ガス消費量(1 次エネルギー換算)の変動

表 4 各キャンパスのガスの用途

\begin{tabular}{|c|c|}
\hline 白山 & $\begin{array}{l}\text { 吸収式冷温水発生機, 㕌房, シャワー室給湯, 実験用（一 } \\
\text { 般教養の自然科学実験） }\end{array}$ \\
\hline 川越 & 厨房, スチーム暖房, 各種実験用 \\
\hline 朝霞 & 吸収式冷温水発生機，厨房 \\
\hline 板倉 & $\begin{array}{l}\text { 吸収式冷温水発生機，厨房，シャワー室給湯， } \\
\text { 実験室植物機能センター }\end{array}$ \\
\hline
\end{tabular}

$\times 10^{6} \mathrm{M} \mathrm{J} /$ 月

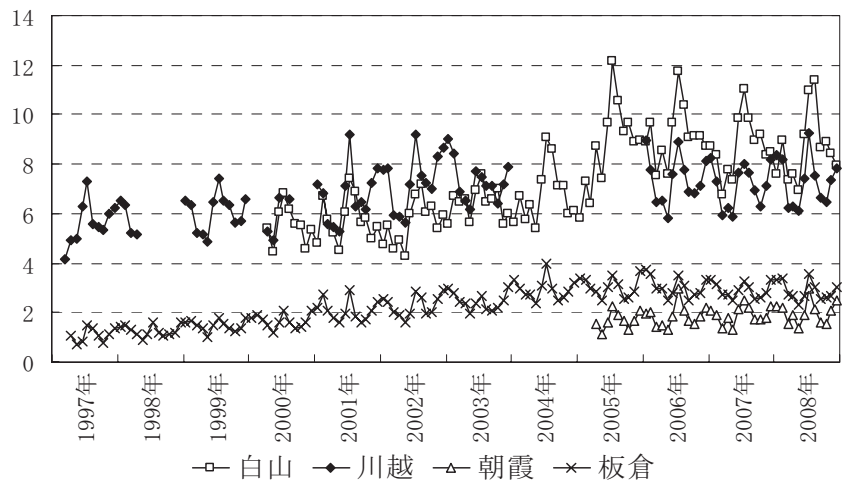

図6 各キャンパスの月間 1 次エネルギー消費量の変動

灯油 : $36.7 \mathrm{M} \mathrm{J} / \mathrm{m}^{3}$

の換算值を、対象期間中を通して適用した。

2.3月間エネルギー消費量の重回帰分析

4 箇所のキャンパスについて月間電気消費量、月間ガス消費量、 
表 5 有意な説明変数のみによる重回帰の結果（冬期月別） （）内はデータ数, 上段：標準偏回帰係数, 下段：偏回帰係数

\begin{tabular}{|c|c|c|c|c|}
\hline \multicolumn{5}{|c|}{ 冬期月別電気消費量kWh／月 } \\
\hline & 白山 (63) & 川越 $(70)$ & 朝霞 (21) & 板倉 $(70)$ \\
\hline \multirow{2}{*}{ 建物延床面積 } & $* * 0.5484$ & $* * 0.3761$ & \multirow{2}{*}{ - } & $* * 0.6201$ \\
\hline & 8.914373 & 13. 09932 & & 9. 548889 \\
\hline \multirow{2}{*}{ 学生数 } & $* * 0.3618$ & $* * 0.3505$ & $* * 0.5784$ & $* * 0.3015$ \\
\hline & 17. 48228 & 210.4053 & 21. 97016 & 27. 05848 \\
\hline \multirow{2}{*}{ 開講日数 } & $* * 0.2044$ & $* * 0.3596$ & $* 0.3726$ & $* * 0.2903$ \\
\hline & 3448.403 & 4416.502 & 942.2718 & 2103. 987 \\
\hline \multirow{2}{*}{ 平均外気温度 } & \multirow{2}{*}{ - } & $* *-0.5740$ & $* *-0.5239$ & $* *-0.2494$ \\
\hline & & -17433.46 & -3424.454 & -4178.565 \\
\hline 定数項 & $* *-462203.3$ & $* *-1062213$ & **133890. 9 & **-58669. 55 \\
\hline 調查済み ${ }^{2}$ & $* * 0.8293$ & $* * 0.8189$ & $* * 0.5729$ & $* * 0.8950$ \\
\hline \multicolumn{5}{|c|}{ 冬期月別ガス消費量M J /月 } \\
\hline & 白山 (51) & 川越 (47) & 朝霞 (21) & 板倉 (69) \\
\hline \multirow{2}{*}{ 建物延床面積 } & \multirow{2}{*}{ - } & \multirow[t]{2}{*}{ - } & \multirow{2}{*}{ - } & $* * 0.5159$ \\
\hline & & & & 0.261135 \\
\hline \multirow{2}{*}{ 開講日数 } & $* *-0.6558$ & \multirow[t]{2}{*}{ - } & $* *-0.2346$ & $* *-0.3975$ \\
\hline & -997.8062 & & -30.69759 & -94.83967 \\
\hline \multirow{2}{*}{ 平均外気温度 } & \multirow{2}{*}{ - } & $* *-0.7737$ & $* *-0.8689$ & $* *-0.4295$ \\
\hline & & -253.0539 & -293.8368 & -232.6311 \\
\hline 定数項 & $* * 41669.78$ & $* * 7621.114$ & **5904. 252 & $* * 2879.782$ \\
\hline 調査済み ${ }^{2}$ & $* * 0.4184$ & $* * 0.5896$ & $* * 0.8784$ & $* * 0.7088$ \\
\hline \multicolumn{5}{|c|}{ 冬期月別重油 (川越) / 灯油 (朝霞) 消費量 $\ell /$ 月 } \\
\hline & 白山 & 川越 (49) & 朝霞 (18) & 板倉 \\
\hline 建物延床面積 & & $\begin{array}{l}* *-0.4131 \\
-2.713988\end{array}$ & - & \\
\hline \multirow{2}{*}{ 開講日数 } & \multirow{4}{*}{ 重油使用なし } & \multirow{2}{*}{ - } & $* * 0.9431$ & \multirow{4}{*}{ 重油使用なし } \\
\hline & & & 299. 8049 & \\
\hline \multirow{2}{*}{ 平均外気温度 } & & $* *-0.6844$ & - & \\
\hline & & -3521.686 & & \\
\hline 定数項 & & $* * 242255.4$ & -69.39311 & \\
\hline 調査済み ${ }^{2}$ & & $* * 0.5768$ & $* * 0.8825$ & \\
\hline \multicolumn{5}{|c|}{ 冬期月別 1 次エネルギー消費量M J /月 } \\
\hline & 白山 (51) & 川越 (51) & 朝霞 (18) & 板倉 (69) \\
\hline 律物䃌床面皘 & - & $* * 0.2795$ & - & $* * 0.6669$ \\
\hline 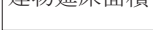 & & 95.97241 & & 119.9473 \\
\hline 兴 & $* * 0.9054$ & $* * 0.3560$ & $* * 0.4598$ & $* * 0.2498$ \\
\hline 子生数 & 417.6418 & 2057.657 & 235.5136 & 264. 4192 \\
\hline 聞講日数 & - & $* * 0.3361$ & $* * 0.4854$ & $* * 0.1233$ \\
\hline & & 42370.08 & 16552.97 & 10454.56 \\
\hline 平均外気温度 & - & $* *-0.6602$ & $* *-0.7140$ & $* *-0.3367$ \\
\hline & & -203031.2 & -62923.98 & -64819.99 \\
\hline 定数項 & 284493.8 & **-7492224 & **1894067 & -261613.3 \\
\hline 調査済み ${ }^{2}$ & $* * 0.8161$ & $* * 0.8296$ & $* * 0.7340$ & $* * 0.8915$ \\
\hline
\end{tabular}

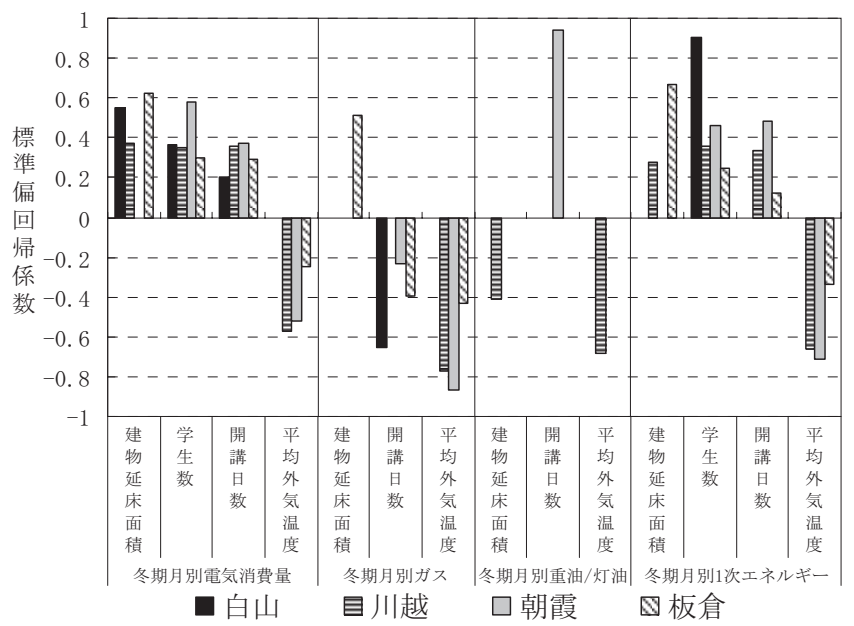

図 7 各説明変数の標準偏回帰係数の比較 (冬期月別)

月間重油消費量、月間灯油消費量、月間 1 次エネルギー消費量それ ぞれを冬期と夏期に分けて目的変数とし、建物延床面積、学生数、 開講日数、平均外気温度を説明変数とする重回帰を行った。この重 回帰において有意とならなかった説明変数を除き、改めて重回帰を
行った。冬期月別の結果を表 5 に示す。

この表では、それぞれのキャンパス毎に標準偏回帰係数、偏回帰係 数と定数項および自由度調整済み決定係数 R 2 を示している。標準 偏回帰係数の前に付した**と*は各説明変数の判定（**は1％有意、 *は $5 \%$ 有意) であり、決定係数の前に付した**と*は重回帰式の検 定結果である。重回帰式が有意とならなかった場合は「成立せず」 としている。

冬期の月間電気消費量は、4 カ所のキャンパスで重回帰式が得ら れた。影響の最も大きい要因は、白山では延床面積、川越では平均 外気温度、朝霞では学生数、板倉では延床面積である。冬期月間ガ ス消費量は、4 カ所のキャンパスで重回帰式が得られた。学生数は いずれのキャンパスでも棄却された。冬期の月間重油消費量は、川 越と朝霞で重回帰式が得られた。川越では平均外気温度、朝霞では 開講日数の影響が大きい。1 次エネルギー消費量については、4カ 所のキャンパスで重回帰式が得られた。白山では学生数、川越と朝 霞では平均外気温度、板倉では延床面積の影響が最も大きい。

各説明变数の標準偏回帰係数の比較を図 7 に示す。延床面積、学 生数、平均外気温度は、重要な変数である場合が多い。白山、朝霞、 板倉で、開講日数はガス消費量において偏回帰係数が負の值をとる。 これらの相関係数は負の值をとる。川越以外では冷暖房の一部に吸 収式冷温水発生機を使用している。教室の冷暖房は多くが分散型パ ッケージ空調方式で、休暇中にも建物を使用する事務室などの空調 系統に主にガスを使用している。このため、開講日数の少ない月に は空調でのガス消費量が大きくなる。ガス消費量について開講日数 と延床面積の偏回帰係数が負となるのは、以上のような事情による もので多重共線性による矛盾ではない。

全ての説明変数による同様の重回帰を夏期の月間消費量について 行い、その結果、有意とならなかった説明変数を除き、改めて重回 帰を行った結果を表 6 に示寸。総じて冬期より重回帰の精度が上が っている。

夏期の月間電気消費量は、全てのキャンパスについて有意な重回 帰式が得られた。影響の大きい要因は、冬期の場合とほぼ同様であ る。夏期のガス消費量では、全てのキャンパスで有意な重回帰式が 得られた。影響の大きい要因は、冬期の場合とほぼ同様である。白 山と川越は決定係数が小さく実用上有効とはいえない。夏期の重油 消費量では、朝霞で重回帰式が得られた。影響の大きい要因は、開 講日数である。1 次エネルギー消費量については、全てのキャンパ スで有意な重回帰式が得られた。朝霞は、決定係数がやや小さい結 果となった。各説明变数の標準偏回帰係数の比較を図 8 に示す。

ガス消費量については、朝霞以外は夏冬とも比較的回帰の精度が 低い。これは川越と板倉では実験にガスを使用していることが大き な要因と思われる。白山の実験用ガス消費量は大きくない。白山の み開講日数の偏回帰係数がマイナスの值となっている。白山の月間 ガス消費量は図 9 に示すように 2 月と 8 月が消費のピークとなって おり、年によるばらつきが大きい。主に夏季休紜中の事務室等の冷 房でのガス消費のためと考えられる。

\section{4 冬期、夏期エネルギー消費量の重回帰分析}

年間のエネルギー消費量について冬期と夏期の 6 ケ月ずつに分け て、重回帰分析を行った。朝霞は年間ではデータ数が少ないので回 帰が成立しない。説明変数は月毎の開講日数が除かれる。建物延床 
表 6 有意な説明変数のみによる重回帰の結果（夏期月別）

（）内はデータ数, 上段：標準偏回帰係数, 下段：偏回帰係数

\begin{tabular}{|c|c|c|c|c|}
\hline \multicolumn{5}{|c|}{ 夏期月別電気消費量kWh／月 } \\
\hline & 白山 (65) & 川越 (72) & 朝霞 $(24)$ & 板倉 (72) \\
\hline \multirow{2}{*}{ 建物延床面積 } & $* * 0.5601$ & $* * 0.3994$ & $* * 0.4192$ & $* * 0.8629$ \\
\hline & 10. 63891 & 14. 32621 & 94. 19238 & 14. 34828 \\
\hline \multirow{2}{*}{ 学生数 } & $* * 0.3017$ & $* * 0.2992$ & \multirow{2}{*}{ - } & \multirow{2}{*}{ - } \\
\hline & 16. 67764 & 188. 2474 & & \\
\hline \multirow{2}{*}{ 開講日数 } & $* * 0.4136$ & $* * 0.5249$ & $* * 0.7239$ & $* * 0.3372$ \\
\hline & 6079.608 & 5434.958 & 1868.742 & 2177.308 \\
\hline \multirow{2}{*}{ 平均外気温度 } & $* * 0.4034$ & **0.8776 & $* * 0.9570$ & $* * 0.3784$ \\
\hline & 18448.09 & 27279.86 & 7510.425 & 7189.693 \\
\hline 定数項 & **-959218. 9 & $* *-1800788$ & $* *-5017462$ & $* *-318161.5$ \\
\hline 調査済み ${ }^{2}$ & $* * 0.9043$ & $* * 0.8412$ & $* * 0.8319$ & $* * 0.8636$ \\
\hline
\end{tabular}

\section{夏期月別ガス消費量 $\mathrm{MJ} /$ 月}

\begin{tabular}{|c|c|c|c|c|}
\hline & 白山 (54) & 川越 (51) & 朝霞 (24) & 板倉 (72) \\
\hline 建物延床面積 & - & - & - & $\begin{array}{l}* * 0.8615 \\
14.32481\end{array}$ \\
\hline 開講日数 & $\begin{array}{l}* *-0.3347 \\
-457.2086\end{array}$ & $\begin{array}{l}* * 0.3885 \\
37.57478\end{array}$ & - & - \\
\hline 平均外気温度 & $\begin{array}{l}* * 0.4678 \\
1951.806\end{array}$ & $\begin{array}{l}* * 0.7133 \\
208.0481\end{array}$ & $\begin{array}{l}* * 0.9026 \\
378.9117\end{array}$ & $\begin{array}{l}* * 0.2151 \\
4086.371\end{array}$ \\
\hline 定数項 & -7381.791 & -279.3627 & $* *-5186.743$ & $* *-210607.6$ \\
\hline 調査済み ${ }^{2}$ & $* * 0.4712$ & $* * 0.3349$ & $* * 0.8062$ & $* * 0.7760$ \\
\hline
\end{tabular}

\section{夏期月別重油(川越) / 灯油 (朝霞) 消費量 $\ell /$ 月}

\begin{tabular}{|c|c|c|c|c|}
\hline & 白山 & 川越 & 朝霞 (8) & 板倉 \\
\hline 開講日数 & \multirow{4}{*}{ 重油使用なし } & \multirow{4}{*}{ 夏期使用なし } & $* * 0.9773$ & \multirow{4}{*}{ 重油使用なし } \\
\hline 呩諘日敕 & & & 300.7423 & \\
\hline 定数項 & & & -22.11985 & \\
\hline 調査済尔 $\mathrm{R}^{2}$ & & & $* * 0.9475$ & \\
\hline
\end{tabular}

\section{夏期月別 1 次エネルギー消費量M J /月}

\begin{tabular}{|l|r|r|r|r|}
\hline & \multicolumn{1}{|c|}{ 白山 (54) } & \multicolumn{1}{c|}{ 川越 $(51)$} & 朝霞 $(23)$ & 板倉 $(72)$ \\
\hline 建物延床面積 & - & $* * 0.3279$ & - & $* * 0.8287$ \\
& & 107.6991 & & 152.6895 \\
\hline \multirow{2}{*}{ 学生数 } & $4 * 0.7528$ & $* * 0.3205$ & - & - \\
\hline \multirow{2}{*}{ 開講日数 } & $* * 1.3633$ & 1772.391 & & $* .2113$ \\
& 36878.43 & $* * 0.5271$ & $* * 0.6208$ & $* * 0.3071$ \\
\hline 平均外気温度 & $* * 0.4974$ & $* * 0.9246$ & $* * 1.0427$ & $* * 0.4929$ \\
& 265142.3 & 270219.1 & 142244.1 & 103779.5 \\
\hline 定数項 & $* *-6071511$ & $* *-1486787$ & $* *-1714867$ & $* *-3867922$ \\
\hline 調査済み $\mathrm{R}^{2}$ & $* * 0.8184$ & $* * 0.8031$ & $* * 0.7557$ & $* * 0.8599$ \\
\hline
\end{tabular}

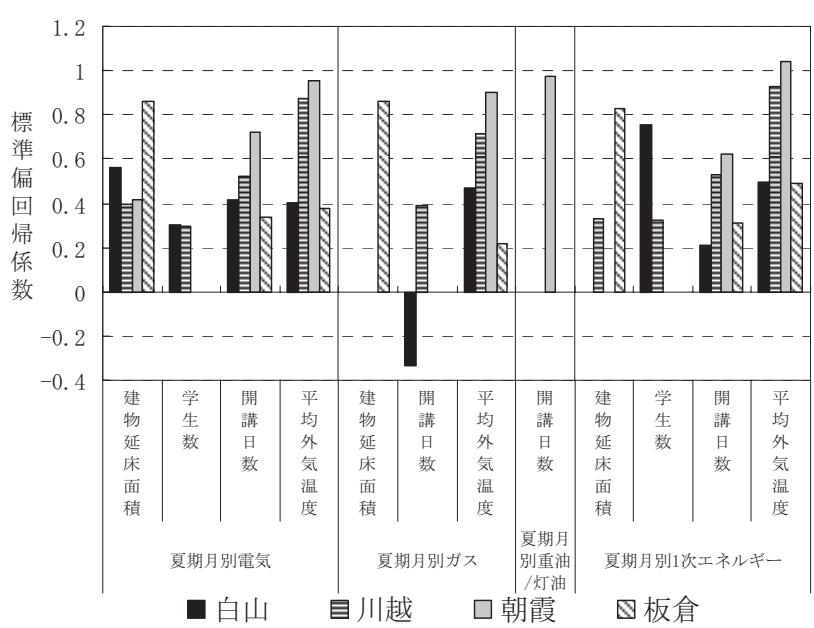

図 8 各説明変数の標準偏回帰係数の比較（夏期月別）

面積、学生数、平均外気温度を説明変数とした場合の結果から、説 明変数が有意なものだけによる冬期 6 ケ月の重回帰の結果を表 7 に 示す。

電気消費量は、 3 キャンパスで重回帰式が得られた。影響の大き い要因は、白山と川越とも延床面積、板倉は学生数である。ガス消 費量は白山と板倉で重回帰式が得られ、影響の大きい要因は学生数

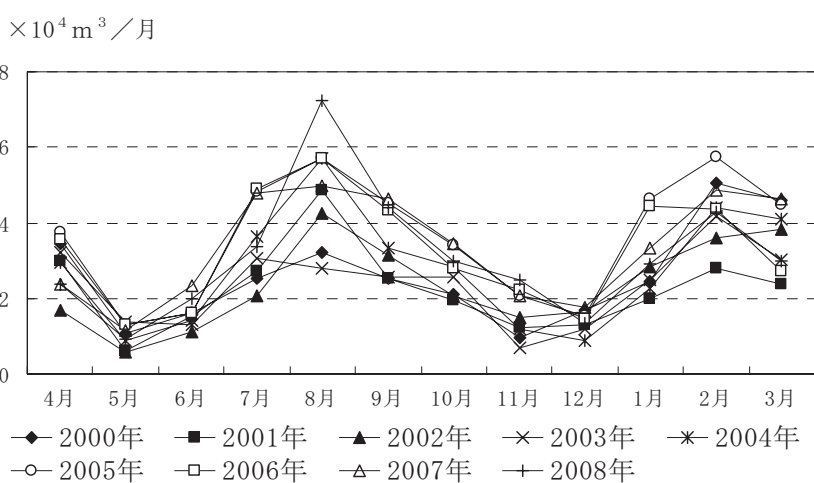

図 9 白山キャンパスの年度別月間ガス消費量

表 7 有意な説明変数のみによる重回帰の結果（冬期）

（ ）内はデータ数, 上段 : 標準偏回帰係数, 下段 : 偏回帰係数

\begin{tabular}{|c|c|c|c|}
\hline \multicolumn{4}{|c|}{ 電気消費量kWh / season } \\
\hline & 白山(11) & 川越 (12) & 板倉 (12) \\
\hline \multirow{2}{*}{ 建物延床面積 } & $* * 0.9893$ & $* * 0.9277$ & \multirow{2}{*}{ - } \\
\hline & 14. 30886 & 27. 36275 & \\
\hline \multirow{2}{*}{ 学生数 } & \multirow{2}{*}{ - } & \multirow{2}{*}{ 一 } & $* * 0.9280$ \\
\hline & & & 82.50827 \\
\hline 定数項 & $* *-556355.5$ & $* *-1088461$ & $* 45122.22$ \\
\hline 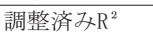 & $* * 0.9763$ & $* * 0.8467$ & $* * 0.8472$ \\
\hline \multicolumn{4}{|c|}{ ガス消費量M J / season } \\
\hline & 白山 (9) & 川越 $(9)$ & 板倉 (12) \\
\hline \multirow{2}{*}{ 学生数 } & $* 0.7856$ & \multirow{4}{*}{ 成立せず } & $* * 0.9117$ \\
\hline & 1. 414654 & & 1. 567747 \\
\hline 定数項 & 5563.485 & & $* * 2541.327$ \\
\hline 調整済み ${ }^{2}$ & $* 0.5624$ & & $* * 0.8144$ \\
\hline \multicolumn{4}{|l|}{ 重油 $\ell$ /season } \\
\hline & 白山(9) & 川越 (9) & 板倉 (12) \\
\hline \multirow{2}{*}{ 建物延床面積 } & \multirow{6}{*}{ 重油使用なし } & $* *-0.9807$ & \multirow{6}{*}{ 重油使用なし } \\
\hline & & -5.131277 & \\
\hline 学生数 & & $* 0.4343$ & \\
\hline & & 55.38563 & \\
\hline 定数項 & & 112454.2 & \\
\hline 調整済み $\mathrm{R}^{2}$ & & $* * 0.8546$ & \\
\hline \multicolumn{4}{|c|}{1 次エネルギー消費量M J / season } \\
\hline & 白山 (9) & 川越 (9) & 板倉 (12) \\
\hline \multirow[t]{2}{*}{ 建物延床面積 } & \multirow{5}{*}{ 成立せず } & $* * 0.8897$ & \multirow[t]{2}{*}{ - } \\
\hline & & 275.7479 & \\
\hline 学生数 & & - & $\begin{array}{r}* * 0.9245 \\
952.597\end{array}$ \\
\hline 定数項 & & $* *-10666897$ & 738092.4 \\
\hline 調整済み $\mathrm{R}^{2}$ & & 0.7656 & $* * 0.8402$ \\
\hline
\end{tabular}

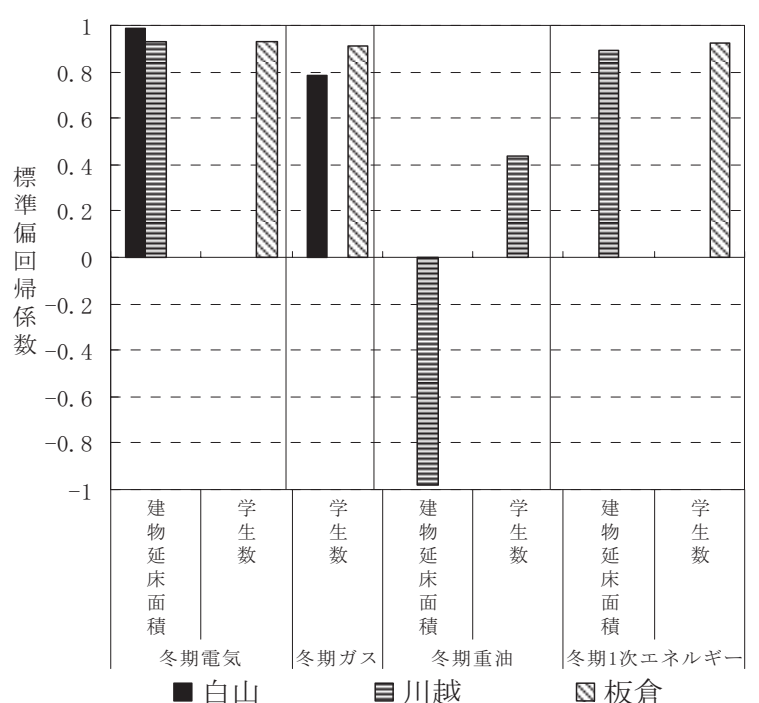

図 10 各説明変数の標準偏回帰係数の比較 (冬期 6 ケ月) 
表 8 有意な説明変数のみによる重回帰の結果（夏期） （ ）内はデータ数, 上段 : 標準偏回帰係数, 下段 : 偏回帰係数

\begin{tabular}{|c|c|c|c|}
\hline \multicolumn{4}{|c|}{ 電気消費量kWh／season } \\
\hline & 白山 (11) & 川越 (12) & 板倉 (12) \\
\hline \multirow{2}{*}{ 建物延床面積 } & $* * 0.9617$ & $* * 0.6313$ & $* * 0.9269$ \\
\hline & 16. 23674 & 13.54363 & 14. 26888 \\
\hline \multirow{2}{*}{ 学生数 } & \multirow{2}{*}{ - } & $* 0.4782$ & \multirow{2}{*}{-} \\
\hline & & 179.9721 & \\
\hline 定数項 & $* *-612810.3$ & $* *-1024364$ & -117341.7 \\
\hline 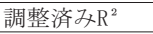 & $* * 0.9164$ & $* * 0.7789$ & $* * 0.8451$ \\
\hline \multicolumn{4}{|c|}{ ガス消費量M J / season } \\
\hline & 白山 (9) & 川越 (9) & 板倉 (12) \\
\hline 建物延床面積 & - & \multirow{6}{*}{ 成立せず } & $\begin{array}{r}* * 0.8840 \\
0.12521\end{array}$ \\
\hline 学生数 & **0.9425 & & - \\
\hline & 1.140501 & & $* * 0.429$ \\
\hline 平均外気温 & - & & 596.5142 \\
\hline 定数項 & 1169.888 & & -13452.6 \\
\hline 調整済み ${ }^{2}$ & $* * 0.8724$ & & $* * 0.8350$ \\
\hline \multicolumn{4}{|c|}{1 次エネルギー消費量／season } \\
\hline & 白山 (9) & 川越 $(9)$ & 板倉 (12) \\
\hline \multirow{2}{*}{ 学生数 } & $* * 0.9774$ & $* 0.7088$ & \multirow{4}{*}{ 成立せず } \\
\hline & 493.77 & 2075.736 & \\
\hline 定数項 & -34083.06 & -2787318 & \\
\hline 調整済み ${ }^{2}$ & $* * 0.9490$ & $* 0.4314$ & \\
\hline
\end{tabular}

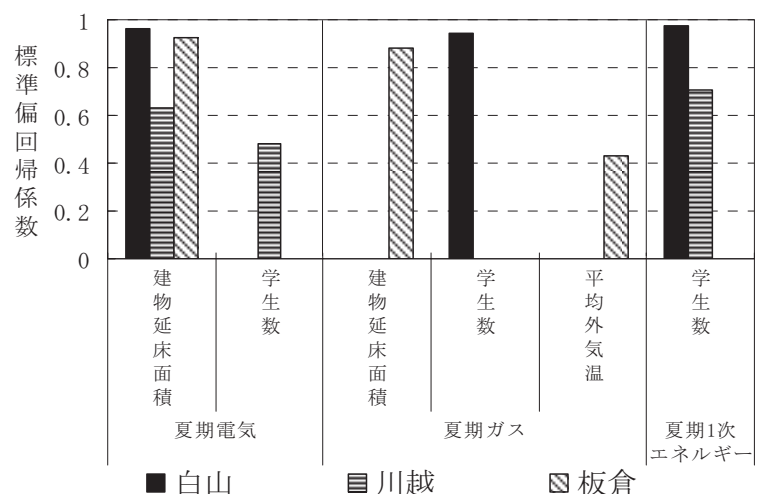

図 11 各説明変数の標準偏回帰係数の比較（夏期 6 个月）

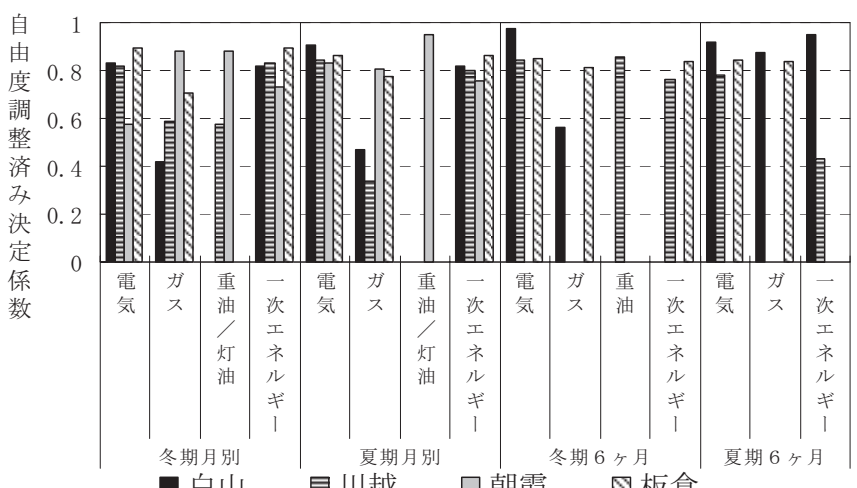

図 12 自由度調整済み決定係数

である。

重油消費量は川越で重回帰式が得られ、延床面積の影響が大きい。 1 次エネルギーは、川越と板倉で重回帰式が得られ、川越は延床面 積が、板倉は学生数の影響が大きい。図 10 は、冬期 6 ケ月の各説 明変数の標準偏回帰係数の比較である。川越のガス消費量は回帰が 成立しない。

夏期についての同様の重回帰の結果を表 8 に示す。
図 11 は、夏期 6 ケ月の各説明変数の標準偏回帰係数の比較であ る。電気消費量は、3キャンパスで重回帰式が得られた。影響の大 きい要因は、白山、川越、板倉で、延床面積である。ガス消費量は、 白山、板倉で重回帰式が得られ、白山は学生数、板倉は延床面積の 影響が大きい。1 次エネルギー消費量は、板倉で重回帰式が成立し ない。川越では、電気消費量は延床面積、学生数による重回帰式が 得られ、ガス消費量については不成立である。板倉は電気とガスが、 延床面積による重回帰式となり、ガス消費量は延床面積と平均外気 温を説明変数とする重回帰式が得られた。

冬期・夏期月別重回帰及び冬期・夏期 6 ケ月の重回帰において、有 効として得られた回帰式の調整済み決定係数を図 12 に示す。白山、 板倉の重油消費量と川越、朝霞の 6 ケ月のガス消費量以外では、高 い值となっており、今後のエネルギー管理の基準值として有用と考 えられる。

\section{3. キャンパス間のエネルギー消費量比較}

\section{1 延床面積あたり 1 次エネルギー消費量での比較}

図 13 は、延床面積あたりの月間 1 次エネルギー消費量の変動状 況である。いずれのキャンパスでも漸増傾向にある。

白山は、川越、板倉に比べて延床面積あたりの月間 1 次エネルギ 一消費量が小さい。これは白山が文系学部のみであることが主要な 原因と考えられる。朝霞は 2005 年 4 月以降、文系学部の教養課程 が白山に移ったため、空室が多い。このため、延床面積あたりの月 間 1 次エネルギー消費量は他に比べて著しく小さい。

\section{2 学生数あたり 1 次エネルギー消費量での比較}

図 14 は学生 1 人あたり延床面積の変動である。白山キャンパス は都心部にあり、学生 1 人あたり床面積は最も小さい。朝霞は学生 1 人当たりの床面積が他に比べ著しく大きいのでこの図からは除い ている。板倉キャンパスは 1997 年に設置されており、それ以来の データである。当初 2 年間は大きな值となっている。

図 15 は学生 1 人あたり月間 1 次エネルギー消費量の変動状況で ある。白山は、文系学部のみで、実験でのエネルギー使用がごく僅 かであること、また、学生 1 人あたり延床面積が小さいので建物ス ペースの利用にエネルギー効率の面から無駄がなく、学生 1 人あた りエネルギー消費量が小さいと考えられる。川越は工学部のみで、 実験等でのエネルギー消費が大きい。安定的であるが 1 人あたり延 床面積の増加に伴って漸増傾向を示している。

朝霞はキャンパス利用の変更により学生数が急激に減った 2005 年度には建物使用計画がこれに対応できず、学生 1 人あたりエネル ギー消費量が著しく大きくなったが、2006 年度ではある程度改善が なされていることが分かる。板倉では 1997 年度にキャンパスが新 設され、当初は、建物は整備されていても、これに見合う数の学生 が居らず、その後、徐々に減少している。2008 年には国際地域学部 が白山第 2 キャンパスに移転した。このため、学生 1 人あたりのエ ネルギー消費量が急増している。

朝霞、板倉の状況は、学生数と建物スペースとの適合性、あるい は学生数に応じた既存の建物スペース使用計画が、エネルギー消費 の合理化にきわめて重要であることを示唆している。これはファシ リティマネジメントの必要性を示すものともいえる。

2002 年度から 2006 年度の延床面積あたり、および学生 1 人あた 


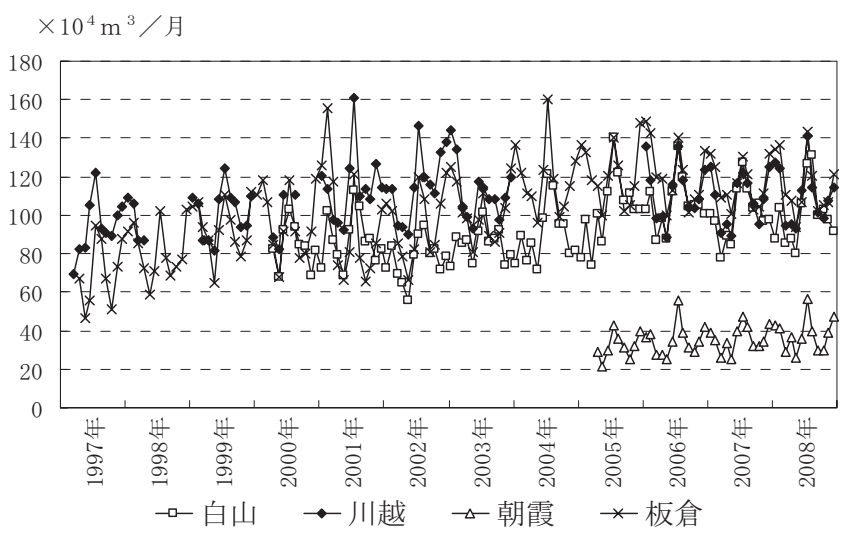

図 13 延床面積あたり月間 1 次エネルギー消費量の変動

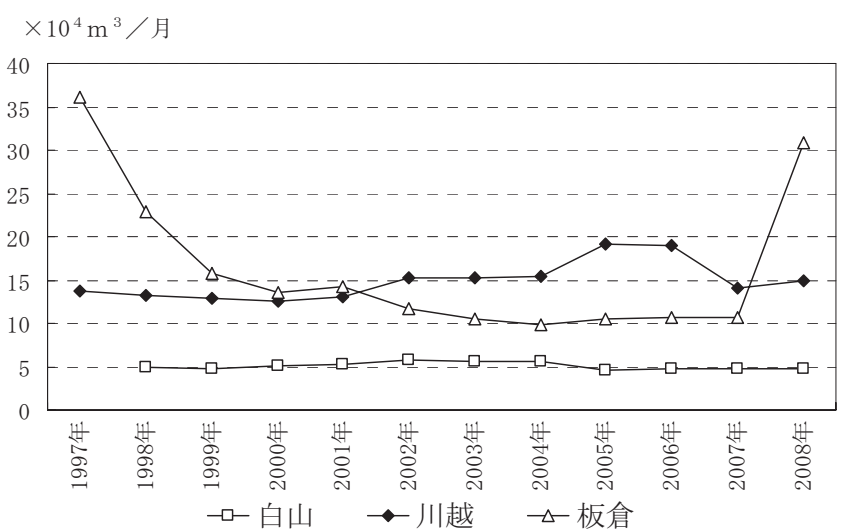

図 14 学生 1 人あたり延床面積の変動

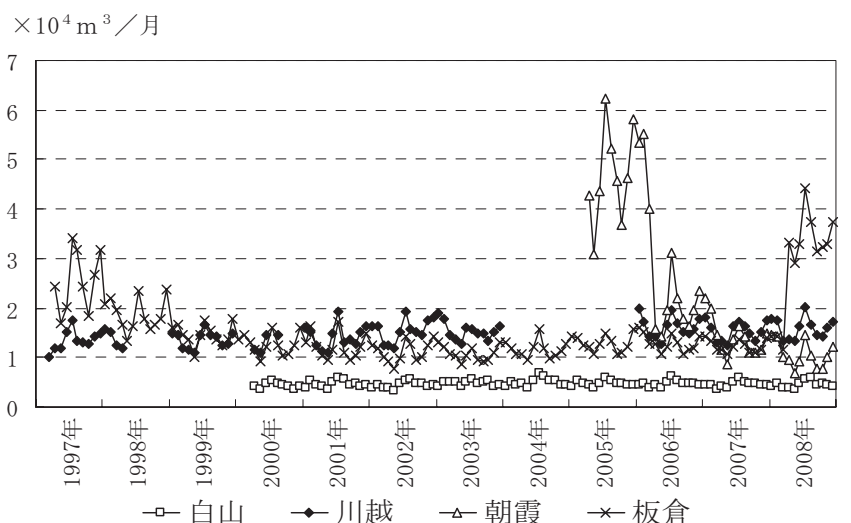

図 15 学生 1 人あたり月間 1 次エネルギー消費量の変動

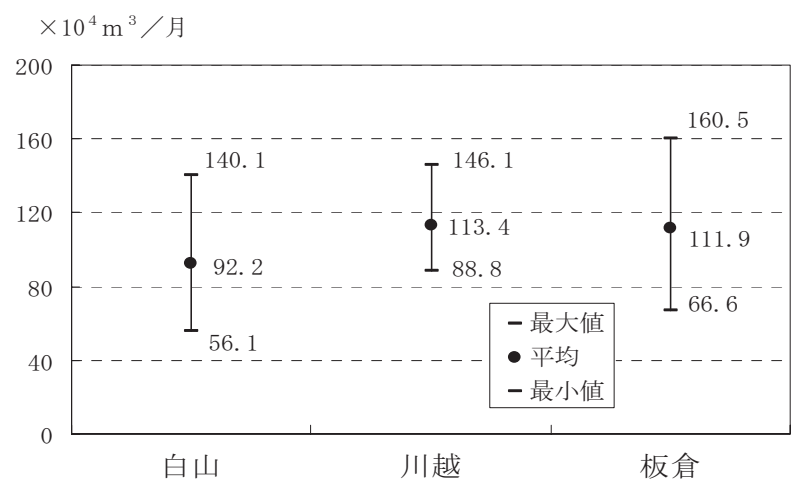

図 16 延床面積あたり平均 1 次エネルギー消費量の比較

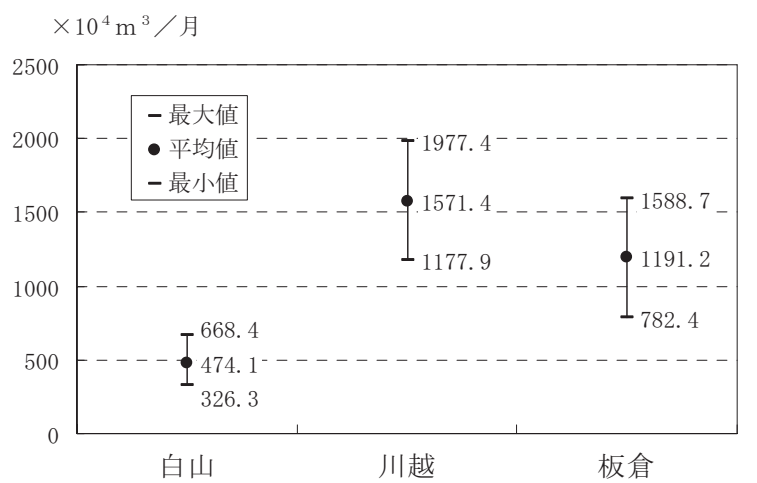

図 17 学生 1 人あたり平均 1 次エネルギー消費量の比較

りの月間 1 次エネルギー消費量の平均值、最大值、最小值を、下記 のような事情のある朝霞を除き、白山、川越、板倉について比較す ると図 16、図 17 のようになる。なお、2008 年は板倉に急激な学生 数の減少が生じたので、朝霞を除外したのと同じ理由で除外した。 工学部のみの川越が最も大きく、理系学部と文系学部が混在する板 倉がこれにつぎ、文系学部のみの白山が最も小さい。延床面積あた りの相違に比して学生 1 人あたりの值の差ははるかに大きい。

\section{結論}

東洋大学の 4 箇所のキャンパスのエネルギー消費に関する長期間 の記録を調查し、これに影響を与える要因を検討して冬期・夏期月 間エネルギー消費量、および冬期・夏期各 6 个月間のエネルギー消 費量を目的変数とする重回帰分析を行った。説明変数は、建物延床 面積、学生数、各月開講日数(月間消費量のみ)、平均外気温度であ り、それぞれのエネルギー消費量への影響の大きさを明らかにした。 標準偏回帰係数から見た各説明変数の目的変数との関係の強さは、 電気、ガス、1 次エネルギーによって、また、各キャンパスによっ て様々であり、共通性はほとんど見られない。開講日数は月間電気 消費量において共通的に有意な説明変数であるが、標準偏回帰係数 （説明力）は大きくない。説明力の最も大きい説明変数は平均外気 温度、学生数、延床面積のいずれかであることが多い。

重回帰式から求められるエネルギー消費量は、当該キャンパスの 諸事情（説明変数の值）に対して標準的な值であると考えられ、管 理基準值として今後のエネルギー管理に有効と考えられる。

以上のようにして、キャンパスのエネルギー消費量の管理基準值 を求めるための重回帰における有効な説明変数を明らかにした。 重回帰分析においては、説明力が高い少数の説明変数で、適合度の 高い（決定係数の大きい）モデルができることが理想とされる。本 研究の重回帰分析では、データの少ない朝霞キャンパスと、消費量 割合の小さいガス消費量の一部に成立しない場合や適合度の低い場 合があったが、他は概ね説明力の高い絞られた説明変数により適合 度の高い回帰式が得られた。

延床面積あたり月間 1 次エネルギー消費量（原単位）をキャンパ ス毎に比較すると、空室が多いという特別な事情を持つキャンパス 以外では、 3 キャンパスで大差はないが都心の文系のみのキャンパ スがやや小さい。一方、学生 1 人あたりの月間 1 次エネルギー消費 量の比較においては、学生 1 人あたり延床面積が小さい都心の文系 キャンパスが顕著に小さかった。また、キャンパス開設時や、キャ 
ンパス利用の変更に伴う学生数の減少により、建物スペースと学生 数の不釣合いが生じ、一時的ではあるが、著しいエネルギーの過剩 消費があったことが明らかになった。ファシリティマネジメントの 必要性を示す結果となった。

\section{謝辞}

本研究に関し、東洋大学管財部よりデータのご提供に関して多大 なるご協力を頂きました。また、データの整理に取り組んだ東洋大 学理工学部生福嶋和樹、三浦大樹君に御協力頂きました。以上、記 して深く謝意を表する。

注

注 1）説明変数のなかで独立性が疑われるのは学生数と建物延床面積である。 川越キャンパスの建物延床面積と学生数の月別データの相関性を見ると付 図 1 のように決定係数が 0.1936 となる。また、年毎のデータの相関性では、 決定係数が 0.2345 となる。両者の相関性はごく低い。多重共線性 ${ }^{16)}$ は重 回帰分析に用いた独立変数の内、共線性が疑われるものを従属変数とし、 他を独立変数として重回帰を行い、その決定係数 $\mathrm{R}_{\mathrm{i}}{ }^{2}$ 上り、許容度 $1-\mathrm{R}_{\mathrm{i}}$ 2 (この逆数が分散拡大係数VIF) を求診断する。この值を求めると、冬 期月別：0.6855、夏期月別：0.8988、冬期 6 ケ月：0.5377、夏期 6 ケ月： 0.8988 となり、多重共線性は問題ない。他のキャンパスでは建物延床面積 と学生数とが同時に説明変数となることが無い。

注 2) 学生数のデー夕は各年 4 月の入学・就学手続き者数による。また、開 講日数のデータは 2008 年度大学が定めた開講日数による。

\section{参考文献}

1）尾島俊雄研究室：早稲田大学理工総研シリーズ 3 建築の光熱水原単位〔東 京版了, 早稲田大学出版部, 1995.6

2）高草木明: 中小規模事務所建物の電気使用量の実態とその変動要因に関寸 る調查研究, 日本建築学会計画系論文集, No.554, pp.101-108, 2002.4

3）小松正佳, 高草木明 : 中規模賃貸事務所ビルにおける熱使用量の実態調查 研究，日本建築学会環境系論文集，No.593，pp.57-64，2005.7

4) JFMA キャンパス F M 研究部会編 : キャンパス F Mガイドブックー大学施 設の戦略的なマネジメントのために一, 日本ファシリティマネジメント推 進協会 (JFMA)，2000.5

5）小崎博明, 平林千義, 伊東民雄, 村上俊博, 荒木佳昭, 磯収二 : 東京工科 大学 CGS (コージェネレーションシステム) の設備保全・運用, 空気調和・ 衛生工学，Vol.76，No.1，pp.23-31，2002.1

6) 三瀬農士，佐藤春樹：慶應義塾大学湘南藤沢キャンパスにおけるコー ジェネレーションシステムの省エネルギー性および環境性評価, 日本建築

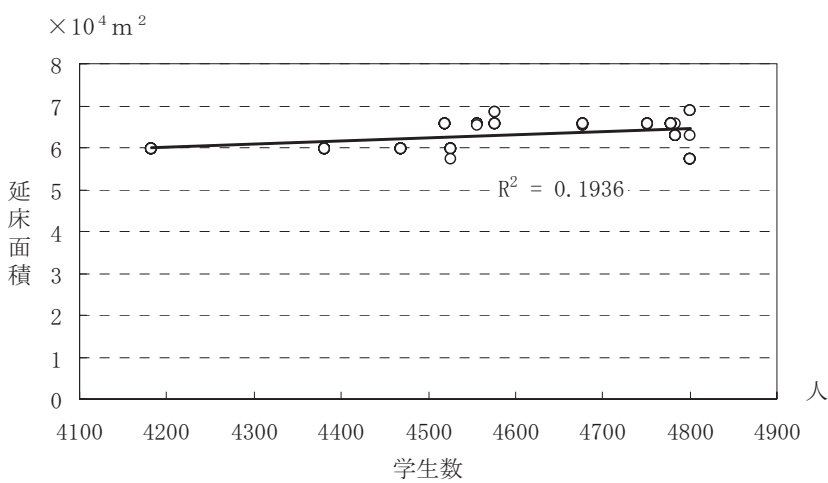

付図 1 延床面積と学生数の独立性

学会環境系論文集,No.616, pp.51-58, 2007.6

7）田畑早也香, 赤司泰義 : 九州大学伊部キャンパスにおける建築物の $\mathrm{CO} 2$ 排出量の推定と評価, 日本建築学会大会学術講演梗概集 (九州), D- 2 分 冊, pp.1149-1150, 2007.8

8）福井拓, 瀧嗾, 八木田裕悟, 川瀬貴晴 : 大学施設の電力消費実態に関寸る 研究（その 1) 千葉大学西千葉キャンパスにおける電力消費実態，日本建 築学会大会学術講演梗概集 (九州), D- 2 分冊, pp.1151-1152, 2007.8

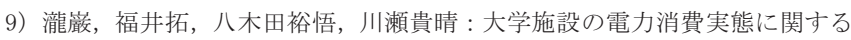
研究（その 2) 建築系研究棟における詳細電力消費実態, 日本建築学会大 会学術講演梗概集 (九州)， D- 2 分冊，pp.1153-1154，2007.8

10）原英嗣: 国士舘大学世田谷キャンパスのエネルギー消費量に関する研究, 日本建築学会大会学術講演梗概集 (九州)，D-2 分冊, pp.119-200, 2007.8

11）石井悦子，沖美帆子，森山正和：神戸大学におけるエネルギー消費の実 態調査その 4 . 原単位の考察と文系学部のアンケート結果, 日本建築学会 大会学術講演梗概集 (九州), D-2 分冊, pp.193-194, 2007.8

12）沖美帆子，石井悦子，森山正和：神戸大学におけるエネルギー消費の実 態調查その 5 . 外気温の年・月の変動とエネルギー消費量, 日本建築学会 大会学術講演梗概集 (九州)， D-2 分冊，pp.195-196，2007.8

13）福田健一, 渡邊俊行, 赤司泰義, 李演生, 江島伊佐朗 : 大学キャンパス の環境・省エネルギー計画に関する研究一その 3 大学施設における電力ガ 又消費量調查, 日本建築学会大会学術講演梗概集（関東）， D- 2 分冊， pp.1167-1168, 2001.9

14）国際エネルギー機関 (IEA) Annex25 : Building Optimization and Fault Diagnosis System Concept, 1993.10

15）中原信生 : 建築設備の省エネルギー手法 8 ）環境・エネルギー管理シス テム (BEMS)，IBEC，No.107，1998.7

16）石村貞夫，デズモンド・アレ：すぐわかる統計用語，東京図書， 1997.6 